\title{
PENINGKATAN HASIL BELAJAR MATEMATIKA MATERI OPERASI PENJUMLAHAN BILANGAN BULAT MELALUI PERMAINAN LOMPAT HENTI
}

\author{
Neneng Eliana \\ Guru SD Negeri 16 Panjak Kabupaten Bengkayan Provinsi Kalimantan Barat \\ nenengeliana@yahoo.com
}

\begin{abstract}
The purpose of this research is to find the increase of mathematics study result with materi operation of adding numeral rounding. where the activity of one cycle consist of 4 component including planning, action, monitoring, and reflection. As data analysis technic, usingqualitative and quantiative data. Qualitative data was obtain by monitoring result along intervention act through field research notes and monitoring notes, while quantitative data was obtain with comparing first assessment average scoring (before action was given) and last assessment. The result of this research find there's increasing in mathematics study result with materi operation of adding numeral rounding through "Stop-Jump" game.
\end{abstract}

Keywords : Mathematics, Stop-Jump Game

\begin{abstract}
Abstrak : Tujuan dari penelitian ini adalah untuk menemukan peningkatan hasil belajar matematika dengan operasi materi menambahkan pembulatan angka. di mana aktivitas satu siklus terdiri dari 4 komponen, termasuk perencanaan, tindakan, pemantauan, dan refleksi. Sebagai teknik analisis data, usingqualitative dan data quantiative. Data kualitatif adalah memperoleh dengan hasil pemantauan di sepanjang intervensi tindakan melalui catatan penelitian lapangan dan pemantauan catatan, sedangkan data kuantitatif adalah mendapatkan dengan membandingkan penilaian pertama rata-rata skor (sebelum tindakan diberikan) dan penilaian terakhir. Hasil penelitian ini menemukan ada yang meningkat dalam hasil studi matematika dengan operasi materi penambahan angka pembulatan melalui "Stop-Jump" permainan.
\end{abstract}

Kata Kunci : Matematika, permainan stop-Jump

Matematika seringkali menjadi momok yang menakutkan bagi sebagian orang, tidak terkecuali bagi anak-anak. Mereka beranggapan bahwa matematika merupakan mata pelajaran yang sulit. Mereka juga beranggapan bahwa mereka tidak berbakat dalam bidang matematika. Anggapananggapan seperti inilah yang membuat mereka pasrah ketika menghadapi kesulitan.
Kalaupun terdapat usaha mengatasinya, namun usaha yang dilakukan kurang maksimal.

Kesulitan yang dihadapi siswa, diperparah lagi dengan usaha yang juga kurang maksimal dari guru. Strategi pembelajaran yang diterapkan kurang menarik minat siswa. Pelajaran matematika menjadi mata pelajaran yang sangat serius. 
Peningkatan Hasil Belajar Matematika Materi Operasi Penjumlahan Bilangan Bulat Melalui Permainan Lompat Henti

Neneng Eliana

Tidak terdapat canda dan tawa. Oleh karena itu minat siswa terhadap mata pelajaran matematika sangat rendah.

Penilaian diri yang tidak tepat oleh siswa, usaha yang kurang maksimal, baik dari siswa maupun guru berpengaruh pada hasil belajar yang dicapai. Pada umumnya hasil belajar matematika di sekolah dasar lebih rendah jika dibandingkan dengan mata pelajaran lainnya. Hal ini terjadi pula di Sekolah Dasar Negeri 16 Panjak. Hasil belajar matematika materi operasi penjumlahan bilangan bulat pada siswa kelas IV sangat rendah. Banyak siswa yang belum mampu menentukan hasil akhir dengan benar. Mereka hanya menebak hasil akhir bertanda positif atau negatif. Hal ini dapat dibuktikan dari hasil tes formatif secara tertulis yang mereka kerjakan. Tes diberikan sebanyak dua kali dengan soal yang sama. Hasil yang diperoleh pada tes pertama dan ke dua menunjukkan perbedaan pada setiap anak. Hal ini menunjukkan bahwa mereka belum memahami materi operasi penjumlahan bilangan bulat.

Menyadari latar belakang masalah di atas, penulis berupaya untuk mengatasinya, yakni dengan menerapkan permainan Lompat Henti. Penerapan permainan Lompat Henti yang menyenangkan diharapkan dapat meningkatkan hasil belajar matematika materi operasi penjumlahan bilangan bulat pada siswa kelas IV di Sekolah Dasar Negeri 16 Panjak.

Belajar adalah suatu proses dimana suatu organisasi berubah perilakunya sebagai akibat pengalaman (Gagne dalam Anitah W, dkk, 2009:1.7). Belajar dapat diartikan mengalami, terjadi di dalam interaksi antara individu dengan lingkungan, baik lingkungan fisik maupun sosial (Anitah, dkk 2009:1.7).

Berdasarkan pengertian di atas, maka dapat disimpulkan bahwa belajar adalah suatu perubahan perilaku seseorang sebagai hasil interaksi individu dengan lingkungan fisik maupun sosial.

Seseorang dapat dikatakan telah berhasil dalam belajar jika ia mampu menunjukkan adanya perubahan dalam dirinya (Wahidmurni, dkk, 2010:18). Sudjana (2010:22) mengutip pendapat Bloom yang menyatakan bahwa perubahanperubahan yang terjadi sebagai hasil belajar di antaranya dari segi kemampuan berpikirnya, keterampilannya, atau sikapnya terhadap suatu objek. Siswa memiliki suatu kemampuan yang dapat ditunjukkan setelah ia menerima pengalaman belajar.

Berkaitan dengan pengalaman belajar, dimana telah terjadi interaksi antara individu dengan lingkungan fisik maupun sosial, maka hal ini berarti telah terjadi suatu aktivitas dalam belajar. Menurut Nasution (2000:89) aktivitas belajar adalah aktivitas yang bersifat jasmani ataupun rohani. Dalam 
proses pembelajaran, kedua aktivitas tesebut harus berkaitan. Seorang siswa akan berfikir selama berbuat, tanpa perbuatan maka siswa tidak akan berpikir. Oleh karena itu, agar siswa aktif berfikir, maka siswa akan diberi kesempatan untuk berbuat dan beraktivitas. Sementara Sugihharto \& Nur (mengemukakan bahwa aktivitas belajar adalah suatu proses kegiatan belajar siswa yang menimbulkan perubahan-perubahan atau pembaharuan dalam tingkah laku atau kecakapan.

Terdapat beberapa faktor yang memengaruhi hasil belajar (Anitah, dkk, 2009:2.7), yaitu: (1) faktor dari dalam diri siswa, di antaranya adalah kecakapan, minat, bakat, usaha, motivasi, perhatian, kelemahan dan kesehatan, serta kebiasaan siswa; (2) faktor dari luar diri siswa, di antaranya lingkungaan fisik dan nonfisik (termasuk suasana kelas dalam belajar, seperti riang gembira, menyenangkan), lingkungan sosial budaya, lingkungan keluarga, program sekolah (termasuk dukungan komite sekolah), guru, pelaksanaan pembelajaran, dan teman sekolah.

$$
\text { Berkaitan dengan matematika, }
$$
Nasution dalam Murniati (2008:45) menjelaskan bahwa istilah matematika berasal dari bahasa Yunani mathein atau manthenein yang artinya mempelajari, namun diduga kata itu erat hubungannya dengan kata Sansekerta medha atau widya yang artinya kepandaian, ketahuan, atau intelegensi. Terdapat beberapa definisi mengenai matematika, antara lain dikemukakan oleh Reys dan Hudojo. Reys dalam Murniati (2008:46) bahwa matematika adalah telaahan tentang pola dan hubungan, suatu jalan atau pola berpikir, suatu seni, suatu bahasa dan suatu alat.

Peraturan Pemerintah No. 19 Tahun 2005, Pasal 63 Ayat (1) menjelaskan bahwa penilaian pendidikan khususnya penilaian hasil belajar peserta didik pada jenjang pendidikan dasar dan menengah terdiri atas: a) Penilaian hasil belajar oleh pendidik; b) Penilaian hasil belajar oleh satuan pendidikan; dan c) Penilaian hasil belajar oleh pemerintah. Dijelaskan lebih lanjut dalam pasal 64 ayat (1) bahwa penilaian hasil belajar yang dilakukan oleh pendidik dilakukan secara berkesinambungan untuk memantau proses, kemajuan dan perbaikan hasil dalam bentuk ulangan harian, ulangan tengah semester, ulangan akhir semester dan ulangan kenaikan kelas. Penilaian hasil belajar oleh pendidik, antara lain digunakan untuk menilai pencapaian kompetensi peserta didik, dimana penilaian yang dilakukan oleh pendidik ini harus berbasis kompetensi, terencana, terpadu, menyeluruh, dan berkesinambungan, sehingga dengan penilaian ini diharapkan pendidik dapat mengetahui tingkat kompetensi yang dicapai oleh setiap siswa, meningkatkan motivasi 
Peningkatan Hasil Belajar Matematika Materi Operasi Penjumlahan Bilangan Bulat Melalui Permainan Lompat Henti

Neneng Eliana

belajar siswa, dan mampu menghantarkan siswa mencapai kompetensi minimal yang telah ditentukan (BSNP).

Standar kompetensi merupakan kompetensi minimal yang harus dimiliki oleh siswa. Kurikulum Tingkat Satuan Pendidikan (2006:425) memuat standar kompetensi matematika sekolah dasar kelas IV Semester 2, yaitu menjumlahkan dan mengurangkan bilangan bulat dengan dengan kompetensi dasar: (1) mengurutkan bilangan bulat, (2) menjumlahkan bilangan bulat, mengurangkan bilangan bulat, (4) melakukan operasi hitung campuran. Sementara guru menjabarkan lagi ke dalam indikator pencapaian kompetensi, antara lain melakukan operasi penjumlahan bilangan bulat. Kriteria Ketuntasan Minimal (KKM) indikator kompetensi ini telah ditentukan oleh guru sebesar 66,67.

Dari paparan di atas dapat dipahami bahwa hasil belajar matematika adalah suatu perubahan yang dapat berupa kemampuan berpikir, keterampilan, atau sikap seseorang sebagai hasil dari pengalaman belajar matematika.

Pengalaman belajar yang diberikan kepada siswa harus sesuai dengan perkembangan siswa. Menurut Bruner kemampuan anak berkembang secara bertahap mulai dari yang sederhana ke yang rumit, mulai dari yang mudah ke yang sulit, dan mulai dari yang nyata atau konkret ke yang abstrak. Urutan tersebut dapat membantu peserta didik untuk mengikuti pelajaran dengan lebih mudah. Bruner menyebutkan tiga tingkatan yang perlu diperhatikan dalam mengakomodasikan keadaan peserta didik, yaitu: (a) tahap pertama enactive (manipulasi objek langsung), (b) tahap ke dua iconic (manipulasi objek tidak langsung), dan (c) tahap ke tiga symbolic (manipulasi simbol) (Gatot Muhsetyo, 2008:1.12).

Sejalan dengan Bruner, Muhsetyo, dkk (2008:3.10-3.11) mengenalkan konsep operasi hitung pada sistem bilangan bulat yang dilakukan melalui tiga tahap. Pada tahap pertama terdapat 2 model peragaan yang dapat dikembangkan, yaitu yang menggunakan pendekatan himpunan (menggunakan alat peraga manik-manik), sedangkan model yang ke dua menggunakan pendekatan hukum kekekalan panjang (menggunakan alat peraga balok garis bilangan atau pita garis bilangan atau tangga garis bilangan). Pada tahap ke dua, proses pengerjaan operasi hitungnya diarahkan menggunakan garis bilangan dan pada tahap ke tiga kepada siswa baru diperkenalkan dengan konsep-konsep operasi hitung yang bersifat abstrak.

Penelitian ini memfokuskan pada materi operasi penjumlahan bilangan bulat. Hal ini dilakukan karena materi operasi penjumlahan bilangan bulat merupakan 
materi prasyarat untuk melakukan operasi pengurangan bilangan bulat. Materi operasi penjumlahan bilangan bulat pada penelitian ini dikenalkan kepada siswa dimulai pada tahap konkret. Pada penelitian ini penulis menggunakan garis bilangan yang digambar pada lantai kelas.

Mayesty dalam Sujiono Sujiono (2010:34) menyatakan bahwa bagi seorang anak, bermain adalah kegiatan yang mereka lakukan sepanjang hari karena bagi anak bermain adalah hidup dan hidup adalah permainan.

Adapun cara dan aturan yang digunakan dalam permainan Lompat Henti ini adalah sebagai berikut:

1) Buatlah garis bilangan di lantai atau tanah dengan kapur.

2) Permainan diawali dengan bersuit antara pemain I dan II.

3) Pemenang suit akan berhak membuat soal operasi penjumlahan pada bilangan bulat, misalnya $5+(-2)$.

4) Lompatan pertama dimulai dari titik 0 yang dilakukan bersama-sama sambil bergandengan tangan. Karena bilangan pertama pada soal bertanda positif, maka arah lompatan menghadap ke positif. Banyaknya lompatan sesuai dengan bilangan pertama pada soal yang telah dibuat

5) Setelah kedua pemain berhenti melompat di titik bilangan yang tepat mereka melakukan suit untuk kali ke dua.

6) Pemenang suit berhak melanjutkan lompatan ke dua. Sementara yang kalah, tetap berada di tempat. Karena bilangan ke dua pada soal bertanda negatif (-2), maka arah lompatannya menghadap bilangan negatif. Banyaknya lompatan sesuai dengan bilangan ke dua pada soal yang telah dibuat (-2).

7) Apabila lompatannya berhenti di titik bilangan yang salah, maka pemain yang kalah pada suitan ke dua berhak melakukan lompatan. Pemenang ditentukan pada ketepatan lompatan ke dua di titik yang tepat (3).

Penelitian mengenai game dan operasi hitung bilangan bulat telah dilakukan oleh Ahmad Faiq Abror. Penelitian tersebut bertujuan untuk membangun sebuah aplikasi game untuk media pembelajaran pada mata pelajaran matematika dengan pokok bahasan operasi hitung bilangan bulat dan mengetahui tingkat kelayakan aplikasi tersebut sebagai media pembelajan pada mata pelajaran matematika kelas VI SD Negeri Jetis 1. Hasil penelitian menunjukkan bahwa tingkat validasi pengembangan media berbasis aplikasi game dari ahli media diperoleh nilai rata-rata 4,32 pada kategori sangat layak, ahli materi diperoleh nilai ratarata 4,34 pada kategori sangat layak, dan penilaian siswa kelas VI SD Negeri Jetis 1 
Peningkatan Hasil Belajar Matematika Materi Operasi Penjumlahan Bilangan Bulat Melalui Permainan Lompat Henti

Neneng Eliana

diperoleh nilai rata-rata 4,36 pada kategori sangat layak. Tingkat kelayakan aplikasi game dapat dilihat pada diagram berikut.

Berdasarkan penelitian yang dilakukan oleh Ahmad Faiq Abror dapat dipahami bahwa permainan yang menyenangkan dapat diterapkan dalam pembelajaran matematika materi operasi hitung bilangan bulat.

Penelitian yang dilakukan oleh penulis di Sekolah Dasar Negeri 16 Panjak, Dusun Panjak, Desa Sahan, Kecamatan Seluas, Kabupaten Bengkayang, Provinsi Kalimantan Barat ini bertujuan untuk meningkatkan hasil belajar matematika materi operasi penjumlahan bilangan bulat pada siswa kelas IV melalui permainan Lompat Henti.

\section{METODE}

Jenis penelitian yang akan digunakan adalah penelitian tindakan kelas (Classroom Action Research) menggunakan pendekatan deskriptif kualitatif. Penelitian ini menggunakan penelitian tindakan model Kemmis dan Taggart. Model penelitian tindakan spiral ini bertujuan untuk memperbaiki atau meningkatkan proses belajar mengajar. Desain intervensi tindakan/rancangan siklus penelitian ini menggunakan model Kemmis dan Taggart (1988:11-14) yang didasarkan atas: (1) perencanaan, (2) tindakan, (3) pengamatan, dan (4) refleksi. Hubungan antara komponen tersebut menunjukkan sebuah siklus atau kegiatan berulang.

Penelitian ini dilakukan di Sekolah Dasar Negeri 16 Panjak, Desa Sahan, Kecamatan Seluas, Kabupaten Bengkayang, Provinsi Kalimantan Barat. Waktu penelitian pada tahun pelajaran 2015/2016 yang dilaksanakan pada bulan Januari sampai dengan bulan Februari 2016.

Penelitian dilaksanakan dalam 2 siklus dan setiap siklus terdiri atas 2 kali pertemuan dengan waktu 2 x 35 menit setiap pertemuan. Karena materi operasi penjumlahan bilangan bulat merupakan materi prasyarat bagi materi selanjutnya, yaitu operasi pengurangan bilangan bulat, maka pelaksanaan penelitian dilakukan pada jam pelajaran efektif.

Penelitian ini menggunakan dua data, yaitu data pemantau tindakan (proses) dan data penelitian (hasil). Data yang diperoleh dari kesesuaian pelaksanaan dengan rencana tindakan merupakan data pemantau tindakan. Sementara data yang diperoleh dari kemampuan awal siswa dalam perolehan skor hasil belajar matematika materi operasi penjumlahan bilangan bulat merupakan data penelitian yang menjadi fokus penelitian dengan sumber data siswa kelas IV SDN 16 Panjak yang berjumlah 34 siswa.

Keberhasilan tindakan ditentukan oleh besarnya prosentase kenaikan minimal tindakan dan pencapaian $\mathrm{KKM}$ indikator kompetensi. Adapun besarnya prosentase 
kenaikan minimal tindakan adalah $20 \%$ dan besarnya Kriteria Ketuntasan Minimal (KKM) indikator kompetensi adalah 66,67.

Teknik pengumpulan data dalam penelitian ini dilakukan melalui teknik observasi, lembar penilaian, dan dokumentasi. Teknik-teknik ini dilakukan sesuai dengan data yang diperlukan dalam penelitian. Observasi dilakukan untuk memperoleh data tentang proses pembelajaran. Instrumen obervasi berupa kolom dimensi pengamatan yang berisi pelaksanaan pembelajaran, aspek pengamatan yang berisi kegiatan guru dan siswa, serta kolom keterangan yang berisi ya dan tidak yang harus diisi dengan tanda check list $(\sqrt{ })$ oleh teman sejawat. Hasil belajar siswa berupa skor yang diperoleh melalui tes tertulis. Skor memiliki rentang 010. Hasil yang diperoleh dimasukkan dalam lembar penilaian untuk selanjutnya dianalisis.

Analisis data penelitian dilakukan dengan menguji hipotesis tindakan, yaitu dengan menggunakan perbedaan rata-rata skor siswa sebelum memperoleh tindakan dan setelah memperoleh tindakan. Analisis data ini dilakukan dalam setiap akhir siklus dengan menghitung rata-rata skor siswa dan prosentase kenaikan dengan memperhatikan kriteria keberhasilan tindakan yang telah ditetapkan. Teknik analisis data yang digunakan bertujuan untuk mengetahui pengaruh pemberian tindakan dalam bentuk permainan Lompat Henti pada siswa kelas IV sekolah dasar dalam upaya peningkatan hasil belajar matematika materi operasi penjumlahan bilangan bulat.

\section{Pelaksanaan Tindakan}

Intervensi tindakan peningkatan hasil belajar matematika materi operasi bilangan bulat dilaksanakan dalam 2 siklus yang terdiri atas 2 kali pertemuan setiap siklus. Langkah-langkah kegiatan pada setiap siklus adalah sama. Perbedaannya hanya pada soal yang diberikan secara bertahap sesuai dengan tujuan pembelajaran yang telah ditetapkan. Pada siklus I, pertemuan ke-1, soal yang diberikan dengan hasil 0 sampai dengan 10 (-10). Pada pertemuan ke-2, soal yang diberikan dengan hasil 0 sampai dengan 50 (-50). Sementara pada siklus II, pertemuan ke-1, soal yang diberikan meningkat lagi dengan hasil 0 sampai dengan 100 (-100). Pada pertemuan ke-2, soal yang diberikan dengan hasil 0 sampai dengan 500 (-500).

Pada kegiatan pembelajaran, guru menyampaikan terlebih dulu tujuan yang akan dicapai dan kegiatan yang akan dilakukan hari itu. Kemudian guru melakukan apersepsi. Sebelum melakukan permainan terlebih dulu guru meminta beberapa siswa menyelesaikan soal operasi penjumlahan bilangan bulat di papan tulis. Selanjutnya guru menyampaikan cara dan 
Peningkatan Hasil Belajar Matematika Materi Operasi Penjumlahan Bilangan Bulat Melalui Permainan Lompat Henti

Neneng Eliana

aturan dalam permainan. Secara berpasangan siswa melakukan permainan. Setelah seluruh siswa mendapat kesempatan turut dalam permainan, siswa diminta menyelesaikan soal operasi penjumlahan bilangan bulat di buku tulis. Ketika tiba pada waktu yang telah ditentukan, guru bersama-sama dengan siswa membahas hasil pekerjaan siswa. Selanjutnya guru memberikan penilaian dan mengadakan pemantapan materi pelajaran. Kegiatan refleksi dilakukan antara guru dan siswa. Pembelajaran diakhiri dengan tindak lanjut oleh guru dengan cara menyampaikan materi pelajaran yang akan datang.

Berdasarkan observasi saat intervensi tindakan diberikan, proses pembelajaran berlangsung sangat baik. Guru melakukan langkah-langkah sesuai dengan rencana yang telah dibuat. Sementara semua siswa mendapat kesempatan dalam permainan. Semua siswa tampak antusias mengikuti permainan.

\section{HASIL}

Berdasarkan asesmen awal, hasil penilaian terhadap hasil belajar matematika materi operasi penjumlahan bilangan bulat sangat rendah. Permainan Lompat Henti yang diterapkan oleh penulis pada pembelajaran matematika menambah pemahaman yang mendalam pada siswa, sehingga mampu meningkatkan hasil belajar matematika materi operasi penjumlahan bilangan bulat pada siswa kelas IV Sekolah Dasar Negeri 16 Panjak.

Berdasarkan hasil asesmen awal, hasil belajar matematika materi operasi penjumlahan bilangan bulat pada siswa masih rendah. Dari skor maksimal sebesar 10, siswa hanya mencapai rata-rata skor sebesar 5,03 (50,30\%). Mereka mengalami kesulitan dalam menentukan hasil akhir bertanda positif atau negatif.

Pada siklus I, rata-rata skor yang diperoleh siswa mengalami peningkatan yang tajam. Rata-rata skor yang diperoleh siswa sebesar 8,32 (83,20\%). Artinya, telah terjadi peningkatan sebesar $32,90 \%$. Data ini menunjukkan bahwa hasil intervensi tindakan telah melebihi prosentase kenaikan minimal yang telah ditetapkan sebesar $20 \%$. Namun, dikarenakan belum tercapainya semua tujuan pembelajaran yang telah ditetapkan, maka siklus II harus dilanjutkan sesuai dengan rencana tindakan. Ditinjau dari segi keaktifan, seluruh siswa menunjukkan antusiasme yang tinggi dalam permainan.

Pada siklus II, pemahaman yang semakin mendalam terhadap materi membuat siswa mampu menyelesaikan soal-soal dengan sangat baik. Pada pertemuan ke-1 dan 2 terdapat beberapa anak yang merasa kecewa dengan hasil perolehan skor mereka dikarenakan ketidaktelitian mereka. Namun, mereka mampu menyelesaikan soal dengan benar setelah guru meminta mereka untuk 
memperbaikinya. Hasil asesmen pada siklus II menunjukkan peningkatan. Rata-rata skor yang diperoleh siswa sebesar 8,44 (84,4\%). Artinya, telah terjadi peningkatan sebesar $34,10 \%$. Data ini menunjukkan bahwa hasil intervensi tindakan telah melebihi prosentase kenaikan minimal yang telah ditetapkan sebesar 20\%. Data ini menunjukkan pula keberhasilan dalam pencapaian KKM indikator kompetensi yang telah ditetapkan sebesar 66,67. Ditinjau dari segi keaktifan, seluruh siswa masih menunjukkan antusiasme yang tinggi dalam permainan. Mereka mencari pasangan yang berbeda dengan pasangan sebelumnya.

\section{PEMBAHASAN}

Penerapan permainan Lompat Henti dapat meningkatkan hasil belajar matematika materi operasi penjumlahan bilangan bulat pada siswa. Penerapan permainan Lompat Henti memberi pemahaman yang mendalam kepada siswa kelas IV Sekolah Dasar Negeri 16 Panjak, sehingga hasil belajar matematika materi operasi penjumlahan bilangan bulat menjadi meningkat dengan perolehan ratarata skor sebesar 5,03 pada asesmen awal menjadi 8,44 pada asesmen akhir,

\section{SIMPULAN}

Berdasarkan temuan dan pembahasan, hasil penelitian tindakan "Peningkatan Hasil Belajar Matematika Materi Operasi Penjumlahan Bilangan Bulat melalui
Permainan Lompat Henti" di Sekolah Dasar Negeri 16 Panjak, Dusun Panjak, Desa Sahan, Kecamatan Seluas, Kabupaten Bengkayang, Provinsi Kalimantan Barat dapat ditarik kesimpulan: (1) hasil belajar matematika materi operasi penjumlahan bilangan dapat ditingkatkan dengan menerapkan permainan Lompat Henti, (2) permainan Lompat Henti dapat meningkatkan hasil belajar matematika materi operasi penjumlahan bilang bulat pada siswa dengan rata-rata skor 5,03 pada asesmen awal menjadi sebesar 8,44 pada asesmen akhir.

Saran yang dapat dikemukakan terkait penelitian ini adalah diterapkannya permainan Lompat Henti di Sekolah Dasar Negeri 16 Panjak maupun sekolah lain sebagai salah satu upaya guru dalam menerapkan strategi pembelajaran yang menyenangkan dan dalam upaya guru meningkatkan hasil belajar matematika materi operasi penjumlahan bilangan bulat.

\section{DAFTAR RUJUKAN}

Anitah W, Sri, dkk. 2009. Strategi Pembelajaran di SD. Jakarta: Universitas Terbuka.

BNSP. 2006. Kurikulum Tingkat Satuan Pendidikan SD/MI. Jakarta: Departemen Pendidikan Nasional. Hudojo, Herman. 1988. Mengajar Belajar Matematika. Jakarta: Proyek 
Peningkatan Hasil Belajar Matematika Materi Operasi Penjumlahan Bilangan Bulat Melalui Permainan Lompat Henti

Neneng Eliana

Pengembangan Lembaga Pendidikan

Tenaga Kependidikan. Dirjendikti.

Kemmis, Stephen \& Robin McTaggart.

1988. The Action Research Planner.

Viktoria: Deakin University.

Muhsetyo, Gatot. 2008. Pembelajaran

Matematika Sekolah Dasar. Jakarta:

Universitas Terbuka.

Murniati, Endyah. 2008. Kesiapan Belajar

Matematika di Sekolah Dasar.

Surabaya: Surabaya Intelektual

Club.

Nasution, S. 2000. Dikdaktik Asas-asas Mengajar. Jakarta: Bumi Aksara.

Peraturan Pemerintah No. 19. 2005.

Santrock, John W. 2002. Life-Span

Development terjemahan Juda

Damanik dan Achmad Chusairi.

Jakarta: Erlangga.

Sudjana, Nana. 2010. Penilaian Hasil Proses

Belajar Mengajar. (Cet. XV).

Bandung: PT. Ramaja Rosdakarya.

Sujiono, Yuliani Nurani dan Bambang Sujiono. Bermain Kreatif Berbasis Kecerdasan Jamak. Jakarta: Indeks, 2010.

Sugihharto \& Afifah Nur. 2011. Pengertian Aktifitas Belajar.

Diakses Januari 2012

http://id.shvoong.com/socialsciences/education/2162643-

pengertian aktivitas-belajar/. 